\title{
Identification of Beta Human Chorionic Gonadotrophin (bHCG) Expression in Frozen Cleavage Embryo of In Vitro Fertilization (IVF) Patients: An Essential Approach for Better Outcome towards Human Being Inheritance in Line with Maqasid Syari'ah Concept
}

\author{
Lokman Md Isa ${ }^{1,2}$, Afzan Mat Yusof ${ }^{1,2}$, Roszaman Ramli ${ }^{3}$, Syamsul Ahmad Arifin ${ }^{1,2}$, Fatin Emalina ${ }^{5}$, Azantee \\ Yazmie Abdul Wahab ${ }^{4}$ \\ ${ }^{1}$ Department of Basic Medical Sciences, Kulliyyah of Nursing, International Islamic University Malaysia(IIUM) \\ Kuantan \\ ${ }^{2}$ IIUM Human Cellular and Molecular Biology Cluster (iMoleC), IIUM Kuantan \\ ${ }^{3}$ IIUM Fertility Centre, IIUM Kuantan \\ ${ }^{4}$ Department of Obstetrics \& Gynaecology (O\&G), Kulliyyah of Medicine, IIUM Kuantan \\ ${ }^{5}$ Department of Biomedical Science, Kulliyyah of Allied Health Sciences, IIUM Kuantan
}

\begin{abstract}
Expression of beta-human chorionic gonadotropin (bHCG) mRNA in early cleavage cell stages is important in predicting embryo viability at blastocyst stage of development. Embryo viability is crucial for in vitro fertilization (IVF) treatment to be successful in terms of increment of implantation and pregnancy rate. In order to establish fertilization outside the human body, optimum condition mimicking the natural body environment like hormones and growth factors as well as impeccable timing must be established. Imam Muslim narrated from Hudhayfa ibn Asad that the Prophet Muhammad (SAW) said: "After the sperm-andovum drop (nut.fa) has been [in the uterus] forty-two days, Allah sends it an angel that gives it form and fashions its hearing, sight, skin, flesh, and skeleton". Therefore the aim of this study is to find the significant association of bHCG expression with early cell stage cleavages and its relationship as predictive marker for potential embryo implantation. Our study focuses on leftover frozen embryos from eight patients consists of six pregnant patients and two non-pregnant patients. We assessed the human bHCG mRNA expression at different cell cleavage stages in these frozen embryos using reverse transcriptasepolymerase chain reaction (RT-PCR). Our results have shown three out of eight patients with five to ten cells of blastomeres were expressed with bHCG. This study indicated that bHCG was expressed on frozethawed late cleavage stage of embryos in IVF patients.
\end{abstract}

KEYWORDS: bHCG gene expression, cleavage embryo, pre-implantation embryo, RT-PCR

\section{INTRODUCTION}

Identifying beta-human chorionic gonadotropin (bHCG) gene expression in early cleavage cells is essential in predicting viability of embryo at blastocyst stage development in pregnancy. In in vitro fertilization (IVF) treatment, it is important to know the viability of embryo development as the success rate of IVF is low. All the predictive factors for a successful embryo implantation need to be studied. ${ }^{1}$ HCG is the most widely studied of pregnancy hormone which is primarily produced by

Corresponding author:

Muhammad Lokman Md Isa

Department of Basic Medical Sciences,

Kulliyyah of Nursing

IIUM Human Cellular and Molecular Biology Cluster

(iMoleC)

International Islamic University Malaysia

Jalan Sultan Ahmad Shah, 25200 Kuantan, Pahang

Telephone: +60129645581

Email: lokman@iium.edu.my the embryo and syncytiotrophoblast. ${ }^{2}$ Islam also provides a guideline in order to ensure the perfect formation of any process including human reproductive process. Imam Muslim narrated from Hudhayfa ibn Asad that the Prophet Muhammad (SAW) said: "After the sperm-and-ovum drop (nut.fa) has been [in the uterus] forty-two days, Allah sends it an angel that gives it form and fashions its hearing, sight, skin, flesh, and skeleton."

HCG appears in maternal blood between 6-9 days after conception and the hormone concentration has been detected at various levels in blastocyst culture media. ${ }^{3}$ HCG is a heterodimer structure consists of $a$ and $B$ non-covalent bond subunits. ${ }^{3}$ Whilst the amino acid sequence of a subunit is shared with other glycoprotein hormones, the distinctive sequence of the $B$ subunit impacts biological specificity. One of the HCG variants; bHCG 
molecule, plays a crucial role at the start of pregnancy. ${ }^{4}$ Studying the $b H C G$ gene expression in the early cleavage of embryo development can be utilized as a predictive marker for blastocyst stage development. bHCG can be used as prognostic indicator. According to Hansis et al (2002), early cleavage embryo expresses bHCG as early as 4-cell cleavage stage to 10 -cell cleavage stage. ${ }^{5}$ Thus, embryo viability and pregnancy potential can be predicted with this gene expression pattern which can be applied in normal pregnancy and especially in IVF treatment. ${ }^{6,7}$ This study was carried out at the IIUM Fertility Centre where the embryo samples were collected, frozen and stored. Some samples underwent bHCG expression via RT-PCR technique and the bands were detected using agarose gel electrophoresis technique Hansis et al. (2002). ${ }^{5}$

\section{MATERIALS AND METHODS}

This study has been approved by the IREC, IIUM (IIUM/305/20/4/10/1).

\section{Embryo sampling}

Eight frozen embryos were collected from International Islamic University Malaysia (IIUM) Fertility Center. The samples were thawed from liquid nitrogen storage and transferred into $1.5 \mathrm{~mL}$ Cryovial tube using modified syringe. All of embryos were assessed according the criteria in Tables 1 and 2. After assessments have been done, all of the samples were identified as Grade 1 embryo.

Table 1: Embryo scoring criteria

\begin{tabular}{cl}
$\begin{array}{c}\text { Embryo Scoring } \\
\text { Criteria }\end{array}$ & $\begin{array}{l}\text { Day of embryo development } \\
\text { depends on the cells }\end{array}$ \\
\hline Criteria 1 & $\begin{array}{l}\text { Day 2: 2-4 cells (26-44 hours) } \\
\text { Day 3: 6-8 cells (66-70 hours) } \\
\text { Day 4: Compacted / morula } \\
\text { (90-100 hours) }\end{array}$ \\
Criteria 2 & $<10 \%$ fragmentation \\
Criteria 3 & proportion of blastomeres \\
\hline
\end{tabular}

Table 2: Cleavage scoring criteria

\begin{tabular}{ll}
\hline Grade & Criteria \\
\hline 1 & Embryo exhibits all criteria \\
2 & Embryo exhibits 2 of 3 criteria \\
3 & Embryo exhibits all 1 of 3 \\
4 & Embryo exhibits none of the
\end{tabular}

RNA extraction and first strand CDNA synthesis Total RNA was extracted from all embryo samples and cell line pooled using the PureLink $®$ RNA Mini Kit following the manufacturer's instructions. The quality of extracted and amplified RNA was assessed using the NanoDropw ND-1000 spectrophotometer. The purified RNA was converted into cDNA by using SuperScript ${ }^{\circledR}$ III First -Strand Synthesis System for RT-PCR Kit (The following procedure is designed to convert $1 \mathrm{pg}-5$ $\mu \mathrm{g}$ of total RNA or $1 \mathrm{pg}-500 \mathrm{ng}$ of poly $(\mathrm{A})+$ RNA into first-strand CDNA) following manufacturer's instruction.

Reverse Transcriptase Polymerase Chain Reaction, Detection and Semi-quantification of RT-PCR produts

Reverse transcription followed by RT-PCR was performed with $2.0 \mu \mathrm{L}$ of total RNA in $25 \mu \mathrm{L}$ by using TopTaq DNA Polymerase kit (Qiagen) following manufacturer's instructions. PCR amplification of the CDNA product was carried out by adding $0.125 \mu \mathrm{L}$ of TopTaq DNA polymerase for 35 cycles in a commercial thermocycler in the following conditions: 3 minutes initial denaturation at $94^{\circ} \mathrm{C}, 2$ minutes of denaturation at $94^{\circ} \mathrm{C}$, annealing at $57.2^{\circ} \mathrm{C}$ for 30 seconds, extension for 1 minutes 30 seconds at $72^{\circ} \mathrm{C}$ and final extension at $72^{\circ} \mathrm{C}$ for 10 minutes. Aliquots were then analyzed using $2 \%$ agarose gels containing $0.1 \mu \mathrm{g} / \mathrm{ml}$ ethidium bromide. For all experiments, $6 \mu \mathrm{l}$ of PCR product was loaded and run on a $2 \%$ agarose gel in 0.5 Tris/borate/EDTA buffer (TBE). Ladder marker 100 bp (Invitrogen) were used. Photographs of the gels were generated and visualize by using image analyzer (Alpha Innotech). The intensity of the bands corresponding to PCR products was determined using image analyzer software (Alpha Imager HP Imaging).

\section{Primer Sequence}

bHCG gene primer sequence was designed using Protein Data Base (PDB) and reconfirmed with Basic Logarithm alignment specific Tools (BLAST) database. The sequence was predesigned by Intergrated DNA Technology (IDT). The sequence of primer target gene bHCG used in RT-PCR is; forward primer: 5'-TGTGCTITTCAGCTTGACACAGG-3' and reverse primer: 5' -CGTCTITTGAGGTTGTATCCGCTG3'; with the accession number from NCBI XM_0052259425.1. The peak density of band intensity of each embryo sample were assessed by densitometry analysis performed using the public domain of NIH Image 1.63 program (http:// rsb.info.nih.gov/nih-image/).

\section{Statistical data analysis}

Data were expressed using mean \pm with standard deviation. Non parametric test was used due to small sample size. Mann Whitey analysis was used to identify any significant different between the expressions of bHCG in 2-4 cell stage embryo with $5-10$ cell stage embryo, and $p<0.05$ was taken as significant. 


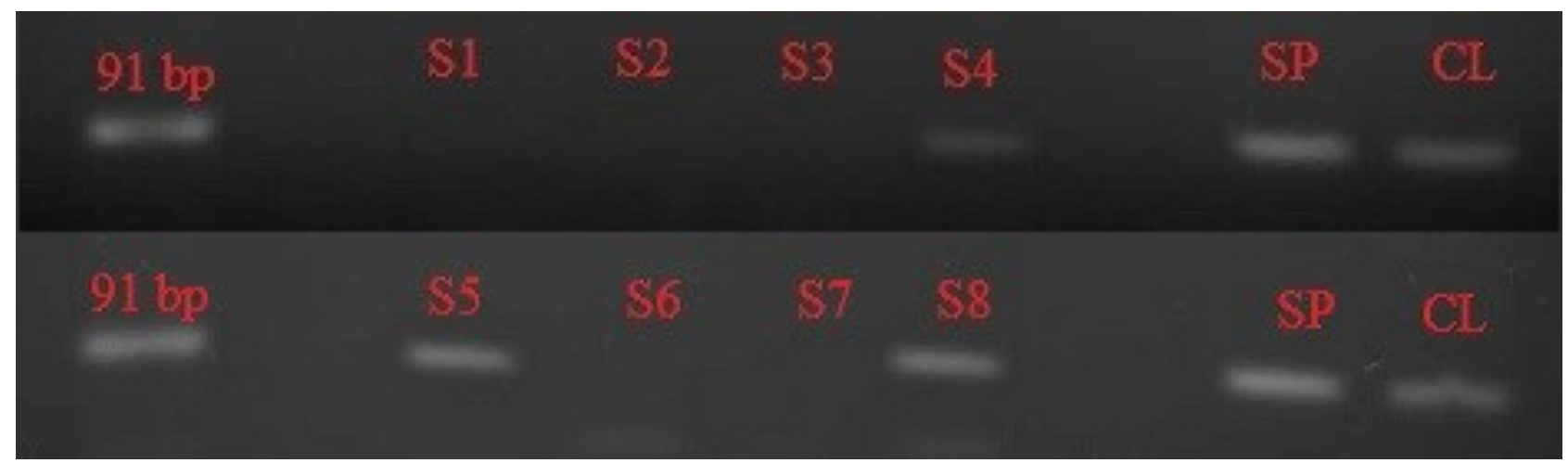

Figure 1 : Verification of PCR product ( $b H C G$ gene) on agarose gel

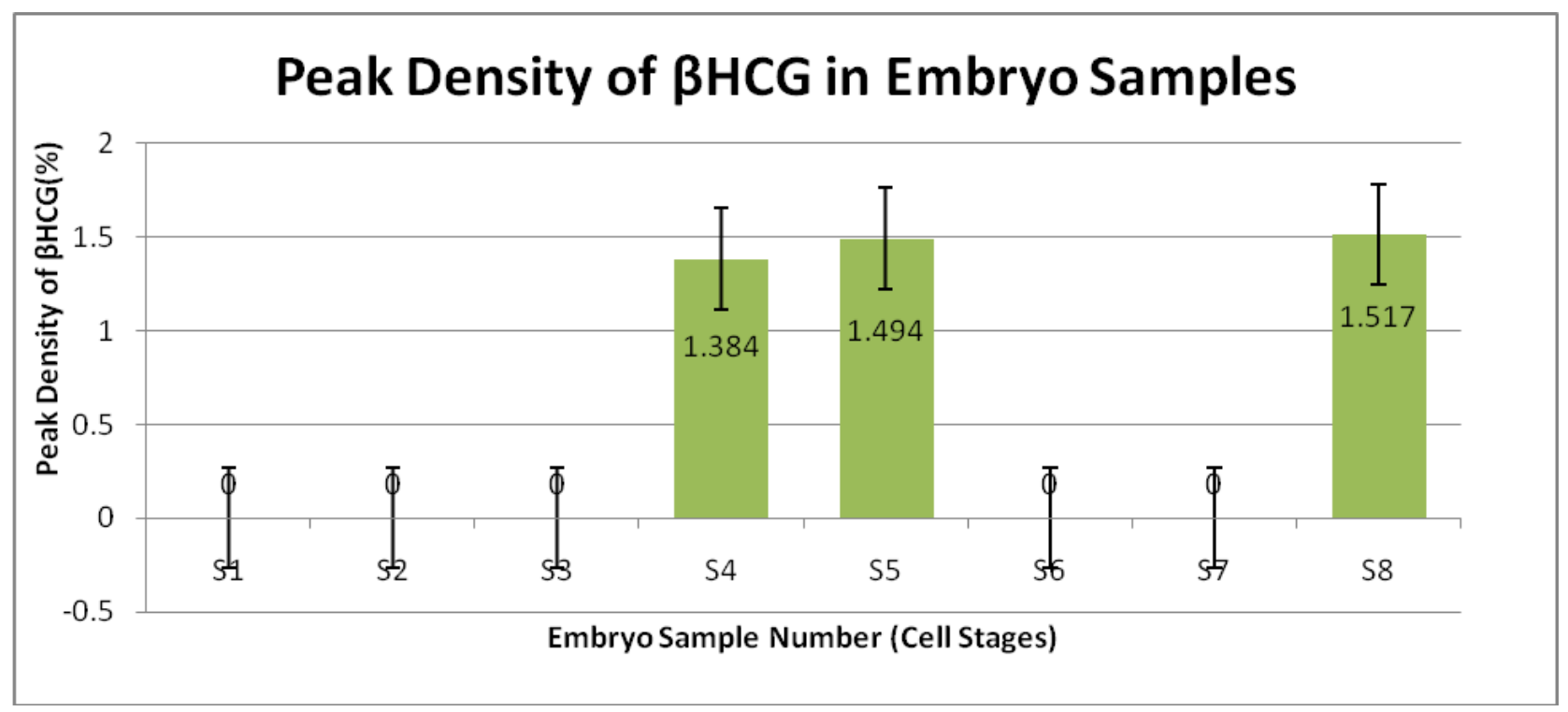

Figure 2 Peak density of $b H C G$ in each embryo samples

\section{RESULTS}

Figure 1 shows the verification of RT-PCR amplification products of bHCG (91 bp) on agarose gel for each sample of the embryo from S1-S8. bHCG product band can be seen in samples $\mathrm{S} 4, \mathrm{~S} 5$ and $\mathrm{S} 8$ whilst other samples did not produce any $b H C G$ product band. Pooled embryo samples (SP) and pooled breast cancer cell and HeLa $(C L)$ were used as positive control in reconfirming the presence of $b H C G$ product using the designated primers. Figure 2 shows the percentage of $b H C G$ peak density in each embryo samples with standard deviation. The highest peak density of $b H C G$ can be seen in S8, and the lowest at $\mathrm{S} 4$ with $1.52 \%$ and $1.38 \%$ respectively. As for samples S1, S2, S3, S6 and S7, all of them have no value of peak density because there were no bands detected.

\section{DISCUSSION}

bHCG is one of the most broadly studied markers for embryonic development and the first to be expressed in human early cell cleavage embryo in comparison to other embryonic development markers. Previous studies have discovered expression of bHCG mRNA as early as 2-cell stage embryo cleavage ${ }^{8-9}$ and 4-cell stage embryo cleavage. ${ }^{5}$ The authors suggested that maternal BHCG MRNA copies were stored in early cleavage cell stages before major embryonic genomic activation was activated. Studies have shown that those BHCG mRNA copies were stored in unfertilized oocytes. ${ }^{3,8,10}$ Therefore it implies that BHCG mRNA could exist in all early cleavage cell stages of embryo development. ${ }^{3,8}$

In contrast to previous reports mentioned earlier, 24 cell stage were unable to be detected in this study. It might be due to BHCG mRNA levels which could not achieve the threshold of detection. Minute degradation of BHCG mRNA was enough to hinder it from being detected during the early cleavage cell stages of embryo samples. Hansis et al. (2002) conceded that undetected BHCG mRNA in early cell stages might be due to consistent degradation of maternal BHCG mRNA to a certain extent during the first cell division and later in BHCG mRNA de-novo synthesis event of which might only take place in selected embryos. ${ }^{5}$ Alternatively, BHCG mRNA might also be stored in oocytes in a polarized pattern, whereby the mRNA could have 
IMJM Volume 17 Special Issue No 2

been diluted to a non-detectable level by the subsequent cell division. Hansis et al. (2002) concluded that $b H C G$ mRNA expression in the state of pre-embryonic genome activation cannot be detected at the threshold of RT-PCR procedure. ${ }^{5}$

Meanwhile, at the 5-10 cell stage of embryo development, BHCG mRNA was sufficient can be detected. As the embryo matures, cells rapidly undergo mitosis. As cell count increases, BHCG mRNA located in the cell nucleus increases in tandem with the cells number which correlated with implantation and pregnancy rates. ${ }^{11}$ This relationship showed its association with the embryo maturity. As it progresses through the stages of cell cleavage, the embryonic genome activation is able to detect $b H C G$ mRNA expression. As the quantity of BHCG mRNA increases, the minute mRNA degradation during extraction and dilution has no effect as detection of BHCG mRNA expression repeatedly shown positive results. ${ }^{5}$

Despite the positive results shown in embryo samples of 5-10 cell stage cell cleavage group, embryo sample $S 6$ appeared negative perhaps due to suppression of bHCG mRNA expression by another marker expression which is Oct-4 mRNA, inner cell mass marker. According to Cauffman et al. (2005), Oct-4 expression might be reactivated in previously negative cells at compacting stages. ${ }^{12}$ Current studies show that Oct-4 mRNA has undergone DNA methylation and histone acetylation modification at consensus of DNA sequences through epigenetics mechanisms which influenced the synthesis and actions of promoters in mRNA synthesis. This modification influences Oct-4 mRNA expression in the trophectodermal cells which immediately upstream Oct-4 gene. ${ }^{13-14}$ In turn, Oct-4 mRNA expression will inhibit $b H C G$ mRNA expression by directly binding to regulatory regions in the $\mathrm{BHCG} 5$, gene promoter. ${ }^{15}$ Furthermore, bHCG mRNA survival or degradation also depends on temporarily bound regulatory proteins or antisense RNA molecules. ${ }^{13}$

However Butler et al. (2013) showed that bHCG molecules production turned positive in all stages of early stage of cell cleavages. ${ }^{4}$ bHCG molecules have been detected in a very high concentration in embryo culture medium starting from 2-, 4-, 6- cell, morula and blastocyst stage of development. Its percentage in terms of molar basis is $100 \%$ and maintains so until the embryo reaches hatched blastocyst stage. The detection of bHCG molecules production in embryo medium cultures proves that there is bHCG mRNA expression in all stages of early embryo cleavages especially in 2-4 cell stage and compacting cell stage which its bHCG expressions appeared negative in this study and study done by Hansis et al. (2002) ${ }^{5}$. Hansis et al. (2002) concluded that the amount of bHCG mRNA expression might be too small and it will only elevate above the threshold of RT-PCR by major embryonic genome activation $^{5}$. As for the compacting cell, perhaps Oct4 mRNA expression may reduce the amount of $b H C G$
mRNA expression which could be too low for RT-PCR to detect.

The association between bHCG mRNA expression and $b H C G$ molecules synthesis does have significant correlation which reflecting $b H C G$ mRNA expression in early cell cleavage stages does have major functions in predicting blastocyst development. It is proven with the detection of $b H C G$ molecules in high level of concentration in embryo medium culture from 2-,4-,6- cell, morula and blastocyst stage development. It shows that bHCG molecules can be an indicator of embryo development. Thus, it can be used to predict embryo viability starting from 2-cell stage up until prior hatched blastocyst development. ${ }^{4}$ Viability of embryo development can be determined based on the detection of bHCG molecules and its level of concentration because bHCG molecules are able to pass through the membrane of the embryo, the zona pellucida, as a selective permeable membrane. Therefore, bHCG hormone is a very good indicator as a prognostic tool in predicting success of implantation and pregnancy. Unbalanced bHCG molecules concentration, too high, too low or none at all, can describe the viability of embryo. From there, embryo quality can be assessed in terms of molecular marker hence corrective or preventive actions can be taken in early stages of embryo development which is beneficial in IVF treatment.

Meanwhile, with regard to pre-implantation genetic diagnosis (PGD), assessment of bHCG mRNA expression in early stages of cell cleavage could generalize its gene existence in chromosome 19 specifically. Its expression can serve as identifying tool for embryogenic blastomeres in combination with testing for chromosome and single gene abnormalities. Further characterization of bHCG mRNAs in cytosolic fractions will provide information regarding the key changes in gene expression that underlie cell development during early embryonic life.

\section{CONCLUSION}

In conclusion, bHCG is expressed in early cleavage stages of embryo development in early cell stages and up until hatched blastocyst stage. Negative result which obtained could be due to low bHCG mRNA quantity and there is interaction with other mRNA expression. Optimization of RT-PCR procedure and other techniques should be undertaken to counter the negative result as its production of molecules shows inversely. Thus, the quantity of $b H C G$ expression depends on cell stage of embryo development. Besides, detection of bHCG mRNA expression shows its existence in chromosome which will indicate confirmation of bHCG molecules production. Confirmation of bHCG molecules production can signify embryo viability in pregnancy which shows $b H C G$ mRNA expression detection can be a predictive marker for potential embryo implantation for IVF treatment. 
By improving the knowledge on human reproductive process, more problems could be solve for the betterment of human life, therefore we should seek more balance finding between science and Islamic principles. In addition the reproductive process is one of the important and sensitive issues like heredity issue in Maqasid Syari'ah; to be thoroughly understood in term of scientific process and also Islamic ethics and principles.

\section{ACKNOWLEDGEMENT}

This study is funded by Ministry of Higher Education Malaysia under the grant of Fundamental Research Grant Scheme, FRGS 2014-2 grant no 14-1480389. The authors are very grateful to the management and technical staffs of IIUM Fertility Centre for their kind cooperation during the study period. The technical assistance from laboratory assistance of Integrated Centre for Research Animal Care and Use (ICRACU) are highly appreciated.

\section{REFERENCES}

1. Edwards RG, Beard HK. Hypothesis: sex determination and germline formation are committed at the pronucleate stage in mammalian embryos. Mol. Hum. Reprod. 1999; 5:595-606.

2. Ramu S, Acacio B, Adamowicz M, Parrett S, Jeyendran RS. Human chorionic gonadotropin from day 2 spent embryo culture media and its relationship to embryo development. Fertil Steril. 2011; 96:615-7.

3. Jurisicova A, Antenos M, Kapasi K, Meriano J, Casper RF. Variability in the expression of trophectodermal markers beta-human chorionic gonadotrophin, human leukocyte antigen-G and pregnancy specific beta-1 glycoprotein by the human blastocyst. Hum Reprod. 1999; 14:1852-8.

4. Butler SA, Luttoo J, Freire MO, et al. Human chorionic gonadotropin (hCG) in the secretome of cultured embryos: hyperglycosylated hCG and hCG-free beta subunit are potential markers for infertility management and treatment. Reprod Sci. 2013; 20:1038-45.

5. Hansis C, Grifo JA, Tang Y, Krey LC. Assessment of beta-HCG, beta-LH mRNA and ploidy in individual human blastomeres. Reprod Biomed Online. 2002; 5:156-61.

6. Kumbak B, Oral E, Karlikaya G, Lacin S, Kahraman S. Serum oestradiol and beta-HCG measurements after day 3 or 5 embryo transfers in interpreting pregnancy outcome. Reprod Biomed Online. 2006; 13:459-64.

7. Carmona F, Balasch J, Creus M, et al. Early hormonal markers of pregnancy outcome after in vitro fertilization and embryo transfer. $J$ of Assist Reprod Genet. 2003; 20:521-6.

8. Adjaye J, Bolton V, Monk M. Developmental expression of specific genes detected in highquality cDNA libraries from single human preimplantation embryos. Gene. 1999; 237:373-83.

9. Bonduelle ML, Dodd R, Liebaers I, et al. Chorionic gonadotrophin-beta mRNA, a trophoblast marker, is expressed in human 8-cell embryos derived from tripronucleate zygotes. Hum Reprod. 1988; 3:909-14.

10. Rull K, Laan M. Expression of beta-subunit of HCG genes during normal and failed pregnancy. Hum Reprod. 2005; 20:3360-8.

11. Ludin K, Bergh C, Hardarson T. Early embryo cleavage is a strong indicator of embryo quality in human IVF. Hum Reprod. 2001; 16:2652-7.

12. Cauffman G, Van de Velde H, Liebaers I, Van Steirteghem A. Oct-4 mRNA and protein expression during human pre-implantation development. Mol Hum Reprod. 2005; 11:17381.

13. Edwards RG, Hansis C. Initial differentiation of blastomeres in 4-cell human embryos and its significance for early embryogenesis and implantation. Reprod Biomed Online. 2005; 11:206-18.

14. Hattori N, Nishino K, Ko YG, et al. Epigenetic control of mouse Oct-4 gene expression in embryonic stem cells and trophoblast stem cells. J Biol Chem. 2004; 279:17063-9.

15. Liu L, Roberts RM. Silencing of the gene for the beta subunit of human chorionic gonadotropin by the embryonic transcription factor Oct-3/4. J Biol Chem. 1996; 271:16683-9. 
